\title{
Musical Insertions in Ms 29 of the National and University Library in Ljubljana (Slovenia)
}

\author{
Jurij SNOJ \\ Institute of Musicology \\ Scientific Research Centre of the \\ Slovenian Academy of Sciences and Arts \\ Novi trg 2, SI-1000 Ljubljana, Slovenia \\ E-mail: snoj@zrc-sazu.si
}

(Received: February 2015; accepted: 20 April 2015)

\begin{abstract}
In Ms 29 of the National and University Library in Ljubljana (Slovenia) an early $13^{\text {th }}$-century copy of Dialogorum libri IV by Gregory the Great - there are two musical insertions: the sequence Celi solem imitantes and the hymn Jam lucis orto sidere. Written in Hungarian notation they were inserted onto blank pages in the completed manuscript in the span of time from the late $13^{\text {th }}$ to the mid-14 ${ }^{\text {th }}$ century. Ms 29 bears a marginal inscription referring to Augustinus Cazottus (Kažotić), Bishop of Zagreb in the early $14^{\text {th }}$ century. It was obviously in his possession. Presumably, the sequence and the hymn were inserted into Ms 29 somewhere in the Diocese of Zagreb, by someone skilled in Hungarian notation.
\end{abstract}

Keywords: Hungarian Strigonian chant notation, Augustinus Cazottus, Gregory the Great, sequence, hymn

Ms 29 of the National and University Library in Ljubljana is a copy of Dialogorum libri IV by Gregory the Great. According to the codicological description of the manuscript by experts of the Austrian Academy of Sciences, it dates from the beginning of the $13^{\text {th }}$ century and was compiled in the southern parts of the German Empire, possibly in the territory of modern Slovenia. ${ }^{1}$ Before coming to its present location, it was owned by the Cistercian Abbey of Kostanjevica (Slovenia), ${ }^{2}$ lying

1. Mittelalterliche Handschriften in Österreich (http://manuscripta.at/m1/hs_detail.php?ID=32764), accessed April 2015. For the first, still valid codicological description of the manuscript, see Srednjeveški rokopisi v Sloveniji / Codices aetatis mediae manu scripti qui in Slovenia reperiuntur, eds Milko Kos - France Stele (Ljubljana: Umetnostno-zgodovinsko društvo, 1931), 53-54, n. 29.

2. German Mariabrunn bei Landstraß, Latin Fons Mariae. 
in the south-eastern part of the medieval land of Carniola (German Krain) just a few miles away from the frontier between the Holy Roman Empire and Croatia, then part of the Kingdom of Hungary.

As a codex, Ms 29 does not show any outstanding features; it is not a book of exceptional standards and was obviously copied only for use. At present it consists of 70 folios $(225 \times 155 \mathrm{~mm})$; however, as evident from the medieval foliation, there were originally at least 126 folios, which is to say that substantial portions of the manuscript have been torn out. The Latin Carolino-Gotica script is not of the highest quality; the text was copied by several more or less careful hands which are difficult to distinguish from one another.

Like many medieval codices, Ms 29 shows traces of a long history. Obviously, Gregory's text was constantly read and reread, as may be gathered from worn out pages of the book. The manuscript contains other interesting material which makes it similar to an archaeological site. The binding consists of wooden covers wrapped up in leather, partly missing. It must be somewhat younger than the book itself since the marginal inscriptions found on some folios appear slightly trimmed. When the copy was bound, parchment folios of other then already destroyed manuscripts were used as binding material: on the inner side of the back cover there is a folio from a $14^{\text {th }}$-century manuscript, pasted there perhaps merely to hide the wooden surface of the cover. The preserved portion of its text contains a description of the Holy Land which could not be identified so far. Before the first and after the last folio of the Dialogues there are two folios taken from a $12^{\text {th }}$-century copy of Moralia in Job likewise by Gregory the Great. Intentionally or by chance, the first scribe of the Dialogues began writing not on the recto but on the verso of the first folio, and the last scribe finished the work in the middle of the verso of the last folio. The first page and the lower part of the last page of the codex therefore remained blank. Onto these two pages someone inscribed two pieces of chant. On the first folio of the manuscript one finds the sequence Celi solem imitantes, which is one of the sequences for the feasts of the apostles, and on the last one there is the hymn Jam lucis orto sidere, sung normally ad primam, in the office of the prime (Table 1).

Thus we have four different textual components in the manuscript. The three folios in the binding of the book were presumably chosen irrespectively of their contents - any parchment having the appropriate size would have fulfilled the task. As for the two chants, no obvious reason for their insertion can be recognized. The manuscript was copied, so that its owner, presumably a community, could read Gregory's work, possibly aloud, but not to sing specific pieces of plainchant. Thus it seems possible that they were inserted there merely out of horror vacui. Yet someone must have made the decision what specific items were to be inserted. This observation leads to the question whether there is any connection between the two chants and the contents of Gregory's Dialogues. To answer it, a look at this interesting work is necessary. 
TABLE 1 Textual components of Ms 29

\begin{tabular}{|l|l|l|}
\hline Folio & Contents & Date \\
\hline binding folio & Gregorii Magni Moralia in Iob & $12^{\text {th }} \mathrm{c}$. \\
\hline $1 \mathrm{r}$ & seq. Celi solem imitantes & $13^{\text {th }} / 14^{\text {th }} \mathrm{c}$. \\
\hline $1 \mathrm{v}-70 \mathrm{v}$ & Dialogorum libri & early $13^{\text {th }} \mathrm{c}$. \\
\hline $70 \mathrm{v}$ & hy. Iam lucis orto sidere & $13^{\text {th }} / 14^{\text {th }} \mathrm{c}$. \\
\hline binding folio & Gregorii Magni Moralia in Iob & $12^{\text {th }} \mathrm{c}$. \\
\hline fol. on back cover & "Descriptio Terrae Sanctae" & $14^{\text {th }} \mathrm{c}$. \\
\hline
\end{tabular}

Gregory's Dialogorum libri are an extensive text in four books, cast in the form of conversation between Gregory himself and a certain Peter. ${ }^{3}$ Gregory speaks about various saints of his and slightly earlier times: bishops, abbots, monks etc., who bore obvious signs of their holiness, manifested in performing various miracles. The first book relates a great many miraculous events from the lives of several Italian bishops and monks. Occasionally, Peter asks for the explanation of the miracles and Gregory interprets them in theological and moral terms. The second book is dedicated to the life of Benedict of Nursia, the founder of western monasticism; it also relates, almost exclusively, miraculous events from his life. The third book resumes the narration on Italian and other bishops and monks. The fourth one starts with a discussion on the immortality of the soul and then continues by describing the deaths of many bishops, abbots, monks and other holy people, deaths which in a miraculous way testify to the immortality of the soul. Gregory's work could be described as a vast collection of miracles which he understood as proofs of God's presence among people. He quite often connects the events described with similar occurrences in the Bible and draws parallels among them by putting the former into the context of salvation history related in the latter. Gregory was obviously not concerned with reporting the events of his time, but strived to see all that was going on in his environment as a continuation of what was described in the Bible.

Comparing the contents of the Dialogues with the text of the sequence Celi solem, a certain degree of relationship can in fact be recognized. The sequence enumerates the apostles, mentioning their activities and their fates, whereas the Dialogues describe, among others, the miracles of several bishops, i.e. successors and followers of the apostles. The sequence on the apostles can thus be regarded as an appropriate introduction to the Dialogues of Gregory, and the selection of this very sequence as a piece to be read or sung immediately before reading the Dialogues might not be entirely accidental. Notwithstanding this connection, whose intentionality cannot be ascertained, all four different components

3. The edition used: Patrologia Latina, vol. LXXVII, ed. J.-P. Migne (Paris, 1849), 149-430 (Books 1, 3, 4); Patrologia Latina, vol. LXVI, ed. J.-P. Migne (Paris, 1847), 125-204 (Book 2). Available online (http:// www.documentacatholicaomnia.eu), accessed April 2015. 
of Ms 29 breathe the same atmosphere and come from the same spiritual world in which human affairs and history function only within the frame of the civitas $D e i$, and are understood and assessed only from the viewpoint of salvation history whose central events took place in the Holy Land.

As Gregory the Great was credited with the regulation and even the composition of the plainchant, it is not out of place to examine his Dialogues from the viewpoint of references to chanting. In the long text there are but few such hints (Table 2). Gregory offers only glimpses into the reality of his times, which holds true also in respect of chanting. Four observations can be made concerning his references to singing: (i) The way in which chanting is mentioned implies that it was something quite common in the monastic and other clerical communities. (ii) In Gregory's view chanting was almost the same as praying. (iii) Chanting is regarded as something that transcends normal human activities: in IV, 10 the dying Abbot Spes joins the psalmody and passes away praying; in IV, 21 two hanged and already dead monks begin chanting; in IV, 14 a dying paralytic by the name of Servulus asks others in the hospital to sing psalms with him; when he suddenly breaks the chanting, all that are present hear something like an echo from the heaven; Servulus concentrates on this celestial singing and passes away; in IV, 15 two invisible choirs, a male and a female one, sing psalms alternately in front of the cell in which the nun Romula is dying; as her soul is ascending to heaven, the singing is gradually fading away. (iv) Examining what is being chanted, one encounters most often psalms (psalmody, also antiphonal), hymns, and lauds, the distinction between hymns and lauds not being clear. This is very similar to what the apostle Paul recommended to Christian communities as their spiritual activities, referring to psalms, hymns and spiritual songs. ${ }^{4}$ In one case, however, an antiphon is explicitly mentioned (IV, 35) which the dying Eleutherius added to the chanting of psalms.

The same lack of historical interest also characterizes Gregory's account of Benedict's life. In a special, very brief chapter (II, 36) he relates that Benedict wrote the monastic rule, but without mentioning either office or chanting.

The two music insertions do not appear to have been written by the same hand. Some characters of the Latin script have the same shape in both texts and were obviously put down in the same way, i.e. by the same strokes of pen, yet the general appearance of the script in the sequence differs from that in the hymn to the extent that it would be risky to perceive the same hand behind both texts. According to the graphic features of the script as well as the music notation, the

4. Col. 3, 16: "Verbum Christi habitet in vobis abundanter, in omni sapientia docentes et commonentes vosmetipsos psalmis, hymnis, et canticis spiritualibus, in gratia cantantes in cordibus vestris Deo.” Eph. 5, 19: “... loquentes vobismetipsis in psalmis et hymnis et canticis spiritualibus, cantantes et psallentes in cordibus vestris Domino." 
TABLE 2 References to chant in Gregory's Dialogorum libri

\begin{tabular}{|c|c|}
\hline Book, chapter & Text \\
\hline $\mathrm{I}, 2$ & Expletis igitur hymnis matutinalibus ... \\
\hline $\mathrm{I}, 9$ & ... prius quam Deo hymnum diceret ... \\
\hline II, 4 & ... et constituta hora, expleta psalmodia sese fratres in orationem dedissent... \\
\hline II, 34 & $\begin{array}{l}\text { Qui tantae ejus gloriae congaudens, omnipotenti Deo in hymnis et laudibus } \\
\text { gratias reddidit ... }\end{array}$ \\
\hline III, 14 & $\begin{array}{l}\text { Nocte vero eadem dum ex more cum fratribus ad exhibendas laudes Domino } \\
\text { surrexisset ... }\end{array}$ \\
\hline III, 22 & ... clericis intra ecclesiam psallentibus ... ... expletisque laudibus Dei ... \\
\hline III, 30 & $\begin{array}{l}\text { Nam cum magna populi multitudine venientes, atque omnipotenti Domino } \\
\text { laudes canentes ... }\end{array}$ \\
\hline III, 31 & $\begin{array}{l}\text { Nam coepit in nocturne silentio psalmodiae cantus ad corpus ejusdem regis et } \\
\text { martyris audiri ... }\end{array}$ \\
\hline IV, 10 & $\begin{array}{l}\text {... cum eis mysticos psalmorum cantus exorsus est. Qui illis psallentibus } \\
\text { orationi intentus animam reddidit. }\end{array}$ \\
\hline IV, 14 & $\begin{array}{l}\text { Studebat semper in dolore gratias agere, hymnis Deo et laudibus diebus ac } \\
\text { noctibus vacare. ... admonuit ut surgerent et cum eo psalmos pro exspectatione } \\
\text { sui exitus decantarent. Cumque cum eis et ipse moriens psalleret, voces } \\
\text { psallentium repente compescuit ... dicens: Tacete; nunquid non auditis quantae } \\
\text { resonent laudes in coelo? Et dum ad easdem laudes quas intus audierat, aurem } \\
\text { cordis intenderet, sancta illa anima carne soluta est. }\end{array}$ \\
\hline IV, 15 & $\begin{array}{l}\text {... in platea ante ejusdem cellulae ostium duo chori psallentium constiterunt, } \\
\text { et sicut se dicebant sexus ex vocibus discrevisse, psalmodiae cantus dicebant } \\
\text { viri, et feminae respondebant. ... Qua [sc. anima] ad coelum ducta, quanto chori } \\
\text { psallentium altius ascendebant, tanto coepit psalmodia lenius audiri, quousque } \\
\text { et ejusdem psalmodiae sonitus ... finiretur. }\end{array}$ \\
\hline IV, 21 & $\begin{array}{l}\text { Facto autem vespere utrorumque eorum spiritus claris illic apertisque vocibus } \\
\text { psallere coeperunt, ita ut ipsi quoque qui eos occiderant, cum voces psallentium } \\
\text { audirent, nimium mirati terrerentur. }\end{array}$ \\
\hline IV, 35 & $\begin{array}{l}\text { Vocatisque fratribus, coram se psallere praecepit, quibus tamen antiphonam } \\
\text { ipse per semetipsum imposuit, dicens: Aperite mihi portas justitiae ... }\end{array}$ \\
\hline IV, 47 & $\begin{array}{l}\text { Alius etiam frater in eodem monasterio Merulus dicebatur, vehementer } \\
\text { lacrymis atque orationibus intentus: psalmodia vero ex ore illius pene nullo } \\
\text { tempore cessare consueverat ... }\end{array}$ \\
\hline
\end{tabular}

insertions may be dated around $1300 .{ }^{5}$ The sequence Celi solem on the first page of the Dialogues, encompassing eight stanzas, is written out in full, but of the five stanzas of the hymn only the first two are to be read on the last page of the Dialogues. Both insertions are poorly preserved and scarcely legible (Plate 1-2).

5. According to the description in Mittelalterliche Handschriften in Österreich they date from the $14^{\text {th }}$ century. 
Plate 1 Ljubljana, National and University Library, Ms 29, fol. 1r

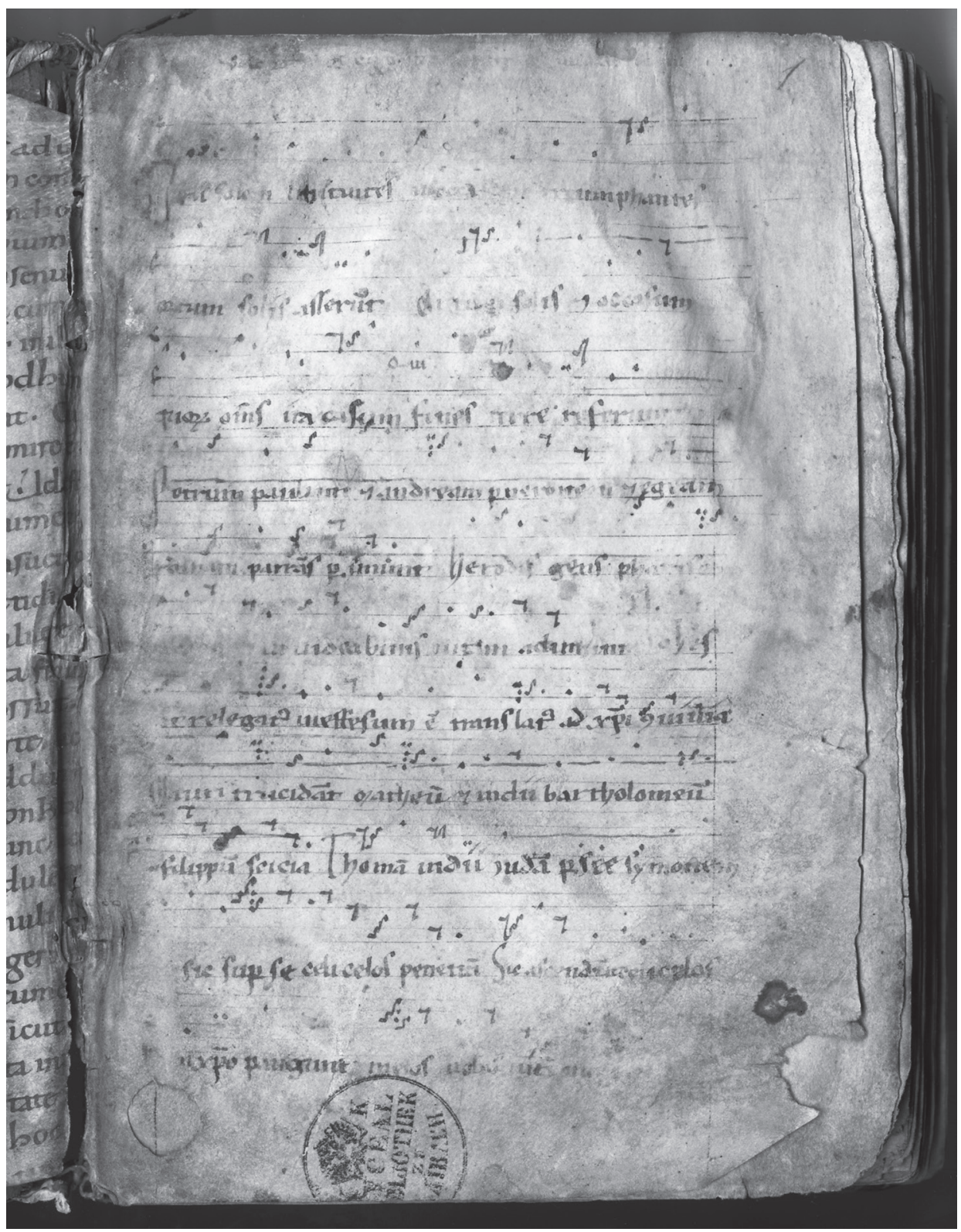


Plate 2 Ljubljana, National and University Library, Ms 29, fol. 70v

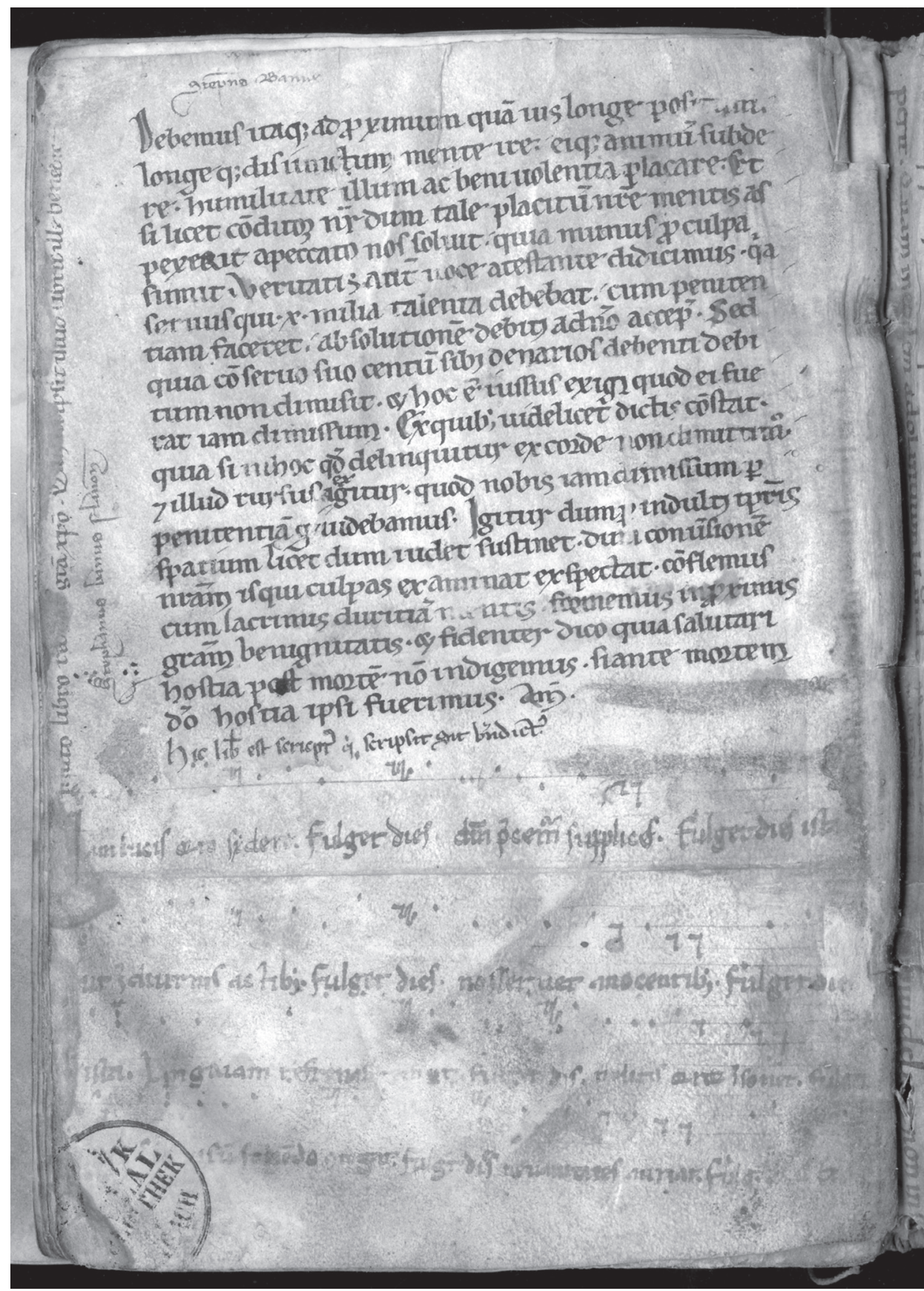


Comparing the text of the sequence to its edition in Analecta hymnica, several variant readings can be observed. ${ }^{6}$ According to the critical apparatus to the edition, some of these variant readings also turn up in a $14^{\text {th }}$-century missal from the Premonstratensian nunnery Chotěšov in Bohemia (southwest of Plzeň). ${ }^{7}$ However, the text in this manuscript differs from the version in Ms 29 in some other places, which is to say that no source of Analecta hymnica exactly matches the text of Ms 29. This fact, inconclusive as it is, illustrates the way of dissemination of medieval liturgical poetry, which was obviously liable to subtle changes and adaptations. More revealing is the observation that apart from two instances the text in Ms 29 agrees with the version in the Missale notatum Strigoniense which was compiled before 1341, possibly in Esztergom, and used in Pozsony (Lat. Posonium, now Bratislava). ${ }^{8}$ It is also very near to a younger, early $16^{\text {th }}$-century gradual from Esztergom, the so-called Gradual of Thomas Bakócz. ${ }^{9}$ This may be taken as an indication that the scribe who made the insertions in Ms 29 copied them from an Eastern European, possibly Hungarian manuscript (Table 3). However, in drawing this conclusion some caution is needed as there exist a great many copies of the sequence. ${ }^{10}$

The scribe who made the first musical insertion in Ms 29 does not appear to have been a very skilled notator: the first half of the second line is notated a third too high; the first half of the fifth line was originally written a third too low, but someone (possibly the same scribe) corrected it and wrote the wrongly notated portion of the melody once again a third higher; the end of the sixth line also seems to be notated faultily ("Johannes"). The comparison of the melody with the version in the Missale notatum Strigoniense reveals several variant readings in the melody - some of them being quite substantial - which are difficult to comment upon (Example 1). ${ }^{11}$ Interestingly, in some cases the melody in the younger Gradual of Thomas Bakócz ${ }^{12}$

6. Analecta hymnica (AH), vol. LV, ed. Clemens Blume (Leipzig: O. R. Reisland, 1886), 5-6, n. 3.

7. Prague, Národní knihovna České republiky, XIV.C.3; see Václav Plocek, Catalogus codicum notis musicis instructorum qui in Bibliotheca publica rei publicae Bohemicae ... servantur (Prague: Academia, 1973), vol. II, 618, n. 192.

8. See Richard Rybarič, "The Codex and its History", in Missale notatum Strigoniense, eds Janka Szendrei - Richard Rybarič (Budapest: Institute for Musicology of the Hungarian Academy of Sciences, 1982) (=Musicalia Danubiana 1$), 13$.

9. H-Efkö, I, 1b (Esztergom, Cathedral Library). See Hymnen und Sequenzen, eds Benjamin Rajeczky - Polikarp Radó (Budapest: Zenemükiadó, 1956) (= Melodiarum Hungariae medii aevi 1), 251, n. 49. In Rajeczky's edition the source bears the designation R 7; it is described on p. XXI. I thank warmly Gábor Kiss, who provided me relevant material concerning Hungarian sources.

10. A recent discussion of sequences in medieval Hungary enumerates 37 sources that include the sequence Celi solem. See Andrea Kovács, "Szekvenciák a középkori Magyarországon - I. Tételkészletek és rítusterületek" [Sequences in medieval Hungary - I. Repertoires and rite areas], Magyar Egyházzene 21 (2013/2014), 259-276; eadem, "Szekvenciák a középkori Magyarországon - II. Liturgikus alkalmazás" [Sequences in medieval Hungary - II. Liturgical assignments], Magyar Egyházzene 21 (2013/2014), 359-376. The list of sources is on p. 371 , footnote 99.

11. Of Missale notatum Strigoniense (S) only the odd stanzas are given since pairs of stanzas share the same melody. Scarcely legible and therefore conjectured melodic progressions are shaded and so are the words. The text of the sequence is given in diplomatic transcription (every stanza begins with a capital).

12. Hymnen und Sequenzen, eds Rajeczky-Radó, 251, n. 49. 
TABLE 3 Variant readings in the sequence Celi solem $^{13}$

\begin{tabular}{|c|c|}
\hline Ms 29 & $\mathrm{~S}, \mathrm{AH}, \mathrm{O}, \mathrm{E}$ \\
\hline $\begin{array}{l}\text { Celi solem imitantes, } \\
\text { in occasu triumphantes } \\
\text { ortum solis asserunt: } \\
\text { Ortum solis et occasum, } \\
\text { quorum omnes ita casum, } \\
\text { fines terre referunt. } \\
\text { Petrum Paulum et Andream } \\
\text { per Neronem et Egeam } \\
\text { Roma Patras perimunt. } \\
\text { Herodis gens pharisea } \\
\text { Jacobis et in Judea } \\
\text { binis vitam adimunt. } \\
\text { Johannes ut relegatus } \\
\text { in Ephesum est translatus } \\
\text { ad Christi convivia. } \\
\text { Mauri trucidant Matheum } \\
\text { et Indii Bartholomeum } \\
\text { et Philippum Scicia. } \\
\text { Thomam Indii Iudam Perse } \\
\text { Symonemque, sic super se } \\
\text { celi celos penetrant. } \\
\text { Sic ascendunt celi celos, } \\
\text { ubi Christo pangunt melos, } \\
\text { nobis vitam impetrant. }\end{array}$ & $\begin{array}{l}\text { S, O: in occasum } \\
\text { AH: afferent - BDMS: asserunt - O: solis ortum adeunt } \\
\text { O: Solis ortum } \\
\text { AH, E: terre fines - O: fines terrae } \\
\text { AH: per - O: et } \\
\text { AH: Herodes - O: Herodis } \\
\text { O: vitam binis } \\
\text { AH: est segregatus - O: ut relegatus } \\
\text { AH: sic manens, ut est vocatus - O: in Ephesum est translatus }\end{array}$ \\
\hline
\end{tabular}

follows the version in the Missale notatum Strigoniense and in other cases the version in Ms 29; there are only a few instances in which it proceeds slightly differently from both sources.

The hymn Jam lucis orto sidere ${ }^{14}$ presents different problems. The text, as written in Ms 29, does not exhibit any variant readings, but it does contain a refrain: each odd verse is followed by the words "fulget dies" and each even one by the words "fulget dies ista." 15 This variety of the text seems to have been rare in the Middle Ages: ${ }^{16}$ it is not to be found in Rajeczky's edition of hymns from

13. Table 3 lists: (i) differences between Analecta hymnica (AH) and Ms 29; (ii) manuscripts that differ from the version in $\mathrm{AH}$ in the same way as Ms 29 (using the symbols of $\mathrm{AH}$ ); (iii) all the differences between Ms 29 and the missal from Chotěšov (in AH codex O); (iv) the differences between Ms 29 and Missale notatum Strigoniense (S); (v) the differences between Ms 29 and the Gradual of Thomas Bakócz (E). The text of Ms 29 has been partly standardized.

14. Analecta hymnica, vol. LI, ed. Clemens Blume (Leipzig: O. R. Reisland, 1908), 40-41, n. 41.

15. In Chevalier's Repertorium hymnologicum this variety has a separate entry: Repertorium hymnologicum, ed. Ulysse Chevalier, vol. I (Louvain: Lefever, 1891), 557, n. 9276. The critical apparatus to the hymn in Analecta hymnica does not mention the refrain.

16. On "fulget dies" as a trope-like insertion in other chants, see Hymnen, ed. Bruno Stäblein (Kassel: Bärenreiter, 1956) (= Monumenta monodica medii aevi 1), 551-552. 
Example 1 Celi solem in Missale notatum Strigoniense (S) and Ms 29 (L)
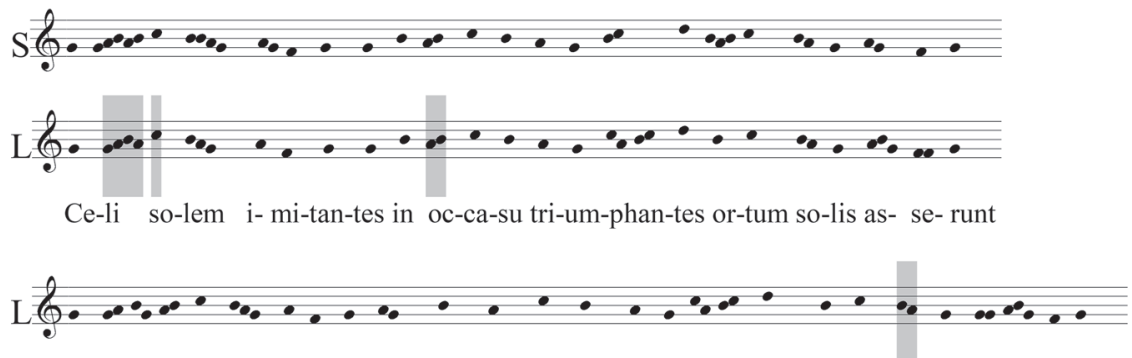

Or-tum so-lis et oc-ca-sum quo-rum om-nes i- ta ca- sum fi-nes ter- re re- fe-runt
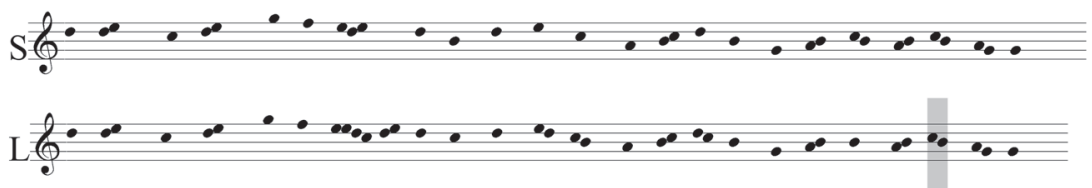

Pe-trum pau-lum et an-dre- am per ne- ro-nem et e- ge-am ro-ma pat-ras per-i- munt

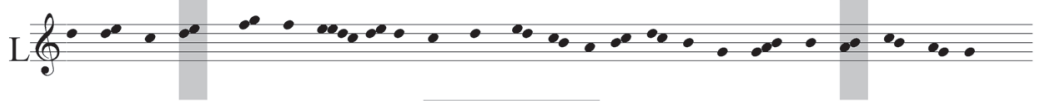

He-ro-dis gens pha-ri- se- a ia-co-bis et in iu-de- a bi-nis vi-tam a- di-munt
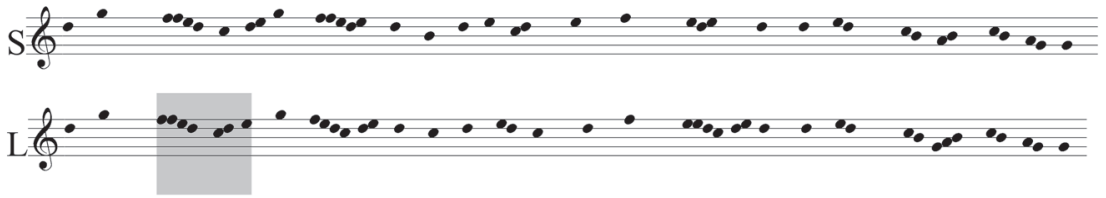

Io-han- nes ut re-le-ga- tus in ef-fe- sum est trans-la- tus ad chris- ti con- vi-vi- a

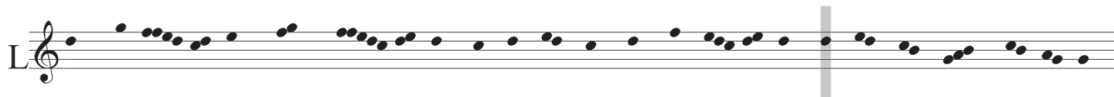

Mau-ri tru- ci-dant ma- the- um et in-dii bar-tho-lo-me- um et fi- lip- pum sci-ci-a
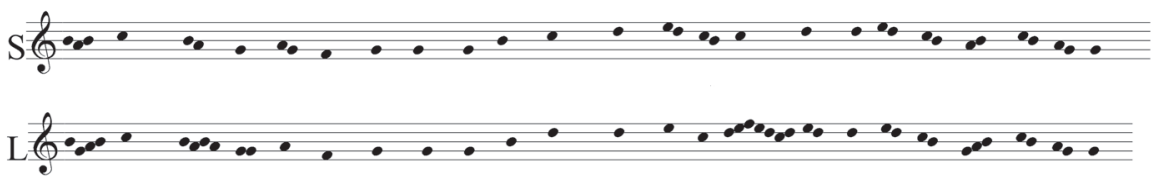

Tho-mam in- dii iu- dam per-see sy- mo-nem-que sic su-per se ce-li ce- los pe-ne-trant

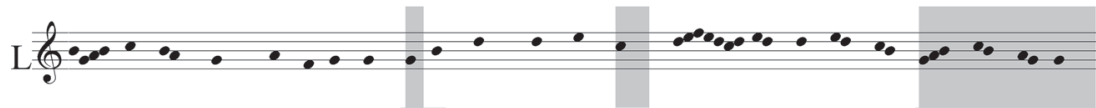

Sic as- cen-dunt ce-li ce-los u-bi chris-to pan-gunt me- los no-bis vi- tam im-pe-trant

S: Missale Notatum Strigoniense

L: Ljubljana, National and University Library, Ms 29 
Hungarian sources, whereas in Stäblein's edition of hymn melodies it appears only once, taken from a $13^{\text {th }}$-century French manuscript. ${ }^{17}$ The melody of Jam lucis orto sidere in Ms 29 might be connected to the mode 8 melody of the French source, yet there are differences between both melodies that could hardly be interpreted as variant readings. The online catalogue of hymn incipits does not help to identify the melody: it contains several incipits very similar to the melody of Ms 29 (starting either on $\mathrm{C}, \mathrm{F}$ or $\mathrm{G}$ ), but no exact match. ${ }^{18}$

Jam lucis orto sidere was sung with a multitude of melodies in the Middle Ages. In a $13^{\text {th }}$-century notated breviary from Paris ${ }^{19}$ it appears with no less than 21 different melodies, but none of them can be recognized as the melody of Ms 29. Numerous Hungarian sources (in which the hymn lacks the refrain) have the same melody as the Vatican edition. ${ }^{20}$ Stäblein's edition comprises 25 different melodies to Jam lucis orto sidere (without the refrain); some of them appear in various versions, but none could be connected to the melody in Ms 29.21 The only source with a melody that is near to Ms 29 is the French manuscript in Sens (Example 2).

Although it is difficult to read the music, it is nevertheless possible to identify the notational signs (Table 4). A single note is always written by a punctum as a small diamond with a thin hair-like stroke on the left. The flexa or clivis has a form that can be encountered in many types of notation. The same is true of the torculus. More characteristic is the podatus, consisting of two small heads connected by a slanting stroke. The most characteristic, however, are the scandicus and the climacus. The scandicus obviously derives from the clivis and may be interpreted as a succession of two clives or a succession of three connected puncta; and the climacus always consists of vertically aligned puncta, the first of which may be doubled. These forms can be encountered in the manuscripts from Klosterneuburg ${ }^{22}$ as well as in Hungarian notation, as for example in the $13^{\text {th }}$-century missal from Zagreb. ${ }^{23}$

17. Hymnen, ed. Stäblein, 116, n. 176. Stäblein's source is Sens, Musée municipal, 46.

18. "Hymn melodies," compiled by David Hiley, in Regensburg's data pool for research on Gregorian chant (http://www.uni-regensburg.de/Fakultaeten/phil_Fak_I/Musikwissenschaft/cantus/), accessed April 2015. The tool presents incipits of hymn melodies from the three most important editions, those of Stäblein, Rajeczky (see above), and Moberg: Die liturgischen Hymnen in Schweden, eds Carl Allan Moberg - Ann-Marie Nilsson (Uppsala: Almqvist and Wiksell, 1991) (= Studia musicologica Upsaliensia, Nova series 13).

19. F-Pn, 15181 (Bibliothèque nationale de France, Département des manuscripts). Available online via Cantus: A Database for Latin Ecclesiastical Chant, maintained by Jan Koláček and Debra Lacoste (http:// cantusdatabase.org/), accessed April 2015.

20. Hymnen und Sequenzen, eds Rajeczky-Radó, 10, n. 23. On page XXXVIII Rajeczky quotes altogether 34 sources including the hymn (without the refrain) with this melody.

21. Hymnen, ed. Stäblein, 3 (twice), 26, 67, 71 (twice), 72 (twice), 73 (thrice), 74 (twice), 75 (twice), 76 (twice), 77, 121, 142, 143, 148, 154, 167, 172 (thrice), 203, 206 (twice), 245, 264, 265 (twice), 266, 360, 451. The online Global Chant Database, maintained by Jan Koláček (http://kolacek.org/content/global-chant-database, accessed April 2015), collecting information from a variety of old and modern sources, includes 38 melodies for Jam lucis (without the refrain); all are different from Ms 29.

22. The prototypes of these signs may already be seen in the famous gradual A-Gu, 807. See Bruno Stäblein, Schriftbild der einstimmigen Musik (Leipzig: VEB Deutscher Verlag für Musik, 1975) (=Musikgeschichte in Bildern III/4), 193.

23. A-GÜ, I/43 (Güssing, Franciscan monastery), see Janka Szendrei, "Graner Choralnotation,” Studia musicologica 30 (1988), 71. 
EXAmple 2 Jam lucis orto sidere in Ms 29

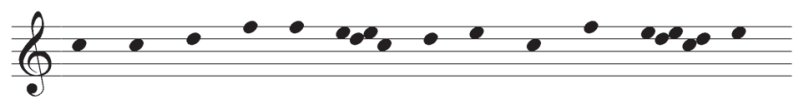

Jam lu- cis or-to sy- de-re. ful-get di- es.

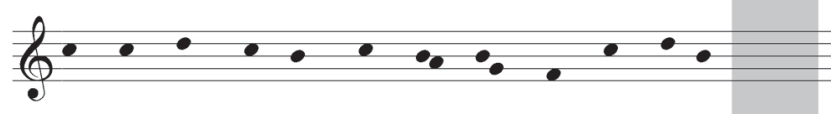

de- um pre-ce-mur sup-pli-ces. ful-get di- es is-ta.

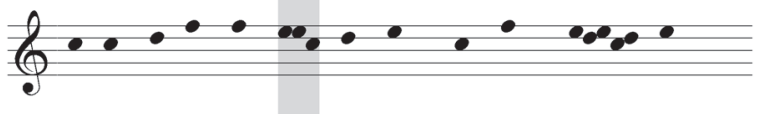

ut in di-ur-nis ac- ti- bus. ful-get di- es.

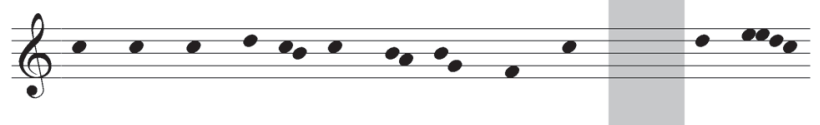

nos ser-vet a no-cen-ti- bus. ful-get di-es is-ta.

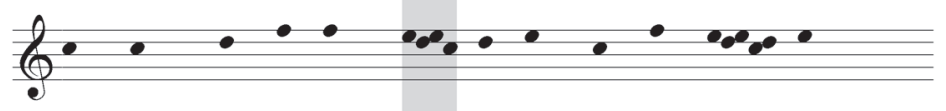

Lin- guam re-fre-nans tem-pe-ret. ful-get di- es.

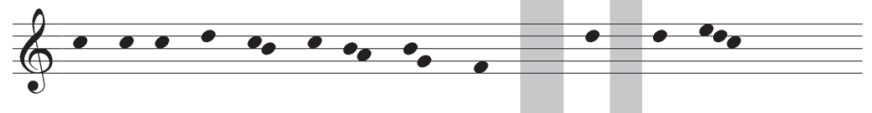

ne li-tis or-ror in-so- net. ful-get di-es is-ta.
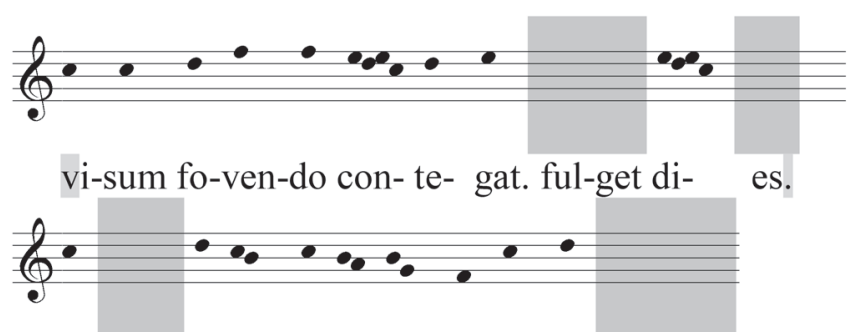

ne va-ni-ta-tes au-ri- at. ful-get di-es is- ta. 

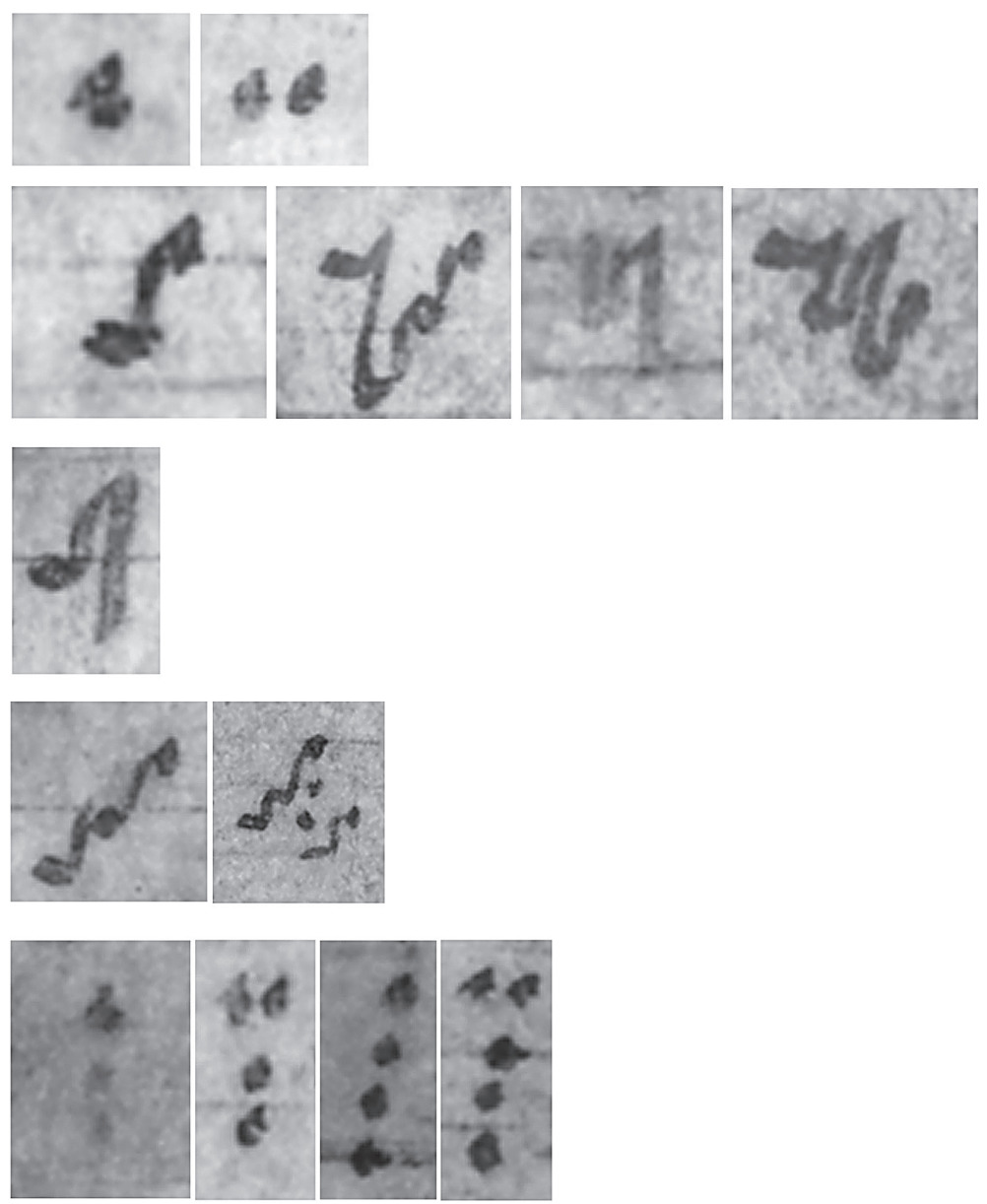

In order to date the musical insertions in Ms 29, the graphical characteristics of their notation should be examined and compared to an array of other manuscripts exhibiting the same type of notation. The largest online catalogue of eastern and central European plainchant manuscripts includes several sources whose notation comes rather close to Ms 29. ${ }^{24}$ The missal from Zagreb (now in Güssing), copied at the beginning of the $13^{\text {th }}$ century, seems older than the musical insertions in Ms 29, whereas the Missale notatum Strigoniense from the beginning of the $14^{\text {th }}$ century might be younger. The notation of the so-called "Istanbul Missal" 25 from the $14^{\text {th }}$ century appears to be of the same age as the musical insertions in Ms 29,

24. Digital Source Catalogue, maintained by Gábor Kiss, Institute for Musicology, Research Centre for the Humanities of the Hungarian Academy of Sciences (http://earlymusic.zti.hu/cd-catalogue/CD_titlepage. htm), accessed April 2015.

25. TR-Itks (Istanbul, Topkap Saray), Deissmann 60 (Digital Source Catalogue). 
and the same is true of some other $14^{\text {th }}$-century manuscripts. ${ }^{26}$ On the basis of these comparisons it can be conjectured that the two pieces were inserted into Ms 29 in the span of time roughly from the end of the $13^{\text {th }}$ century to the mid- $14^{\text {th }}$ century. However, a detailed study, encompassing more comparative sources, may date the insertions with greater precision.

Judging from the notation, the two insertions must have entered Ms 29 somewhere in the territory where Hungarian notation was used. This observation leads to the question whether it is possible to locate the place of their production more precisely. In an attempt to answer this question we must turn to the history of the manuscript. Ms 29 bears traces of a long use, including several marginal inscriptions. The most revealing among them is the first of the three items on fol. $67 \mathrm{v}$. It contains a reference to a certain Augustine, bishop of Zagreb (Table 5).

In the entire history of the Diocese of Zagreb there was only one bishop Augustine: Bishop Augustinus Cazottus (Croatian Augustin Kažotić, Ital. Agostino Casotti). He was born in Trogir in Dalmatia around 1260. As a youth he joined the Dominicans who had already settled in Dalmatia by the mid-13 ${ }^{\text {th }}$ century. In 1286 he was in Pavia, whence he travelled to Paris and studied there for several years. In 1301 he accompanied Cardinal Nicola Boccasini on his mission to Hungary, whose purpose was to prepare the arrival of Charles I from the Capetian House of Anjou (Károly Róbert) as the successor to the Hungarian and Croatian throne. In 1303 Cardinal Boccasini was elected Pope as Benedict XI, and in the same year he appointed Kažotić Bishop of the Zagreb Diocese, which at that time functioned as a suffragan diocese of Kalocsa. Augustine was a man of letters; he is believed to have established the cathedral school in Zagreb and a library; perhaps he was also engaged in matters of liturgy and participated in the formation of the rite of Zagreb. In 1318 he travelled to the court of Pope John XXII in Avignon, where he wrote a treatise on witchcraft, superstition and divination in 1320. He never returned to Zagreb, apparently because the king did not want him there. Presently, in 1322 he was appointed Bishop of Lucera in southern Italy where he died the following year (1323). ${ }^{27}$

When Ms 29 was being bound, the marginal inscription in reference to Kažotić had been slightly trimmed, making spelling of the whole phrase rather ambiguous. The word "pat" is abbreviated and it is not clear whether it stands for "patri" or "patre"; this is to say that the whole phrase could be reconstructed either in the dative or in the ablative case, which leads to two different interpretations. It seems more plausible to read it in the dative case; in this case it could scarcely mean

26. Zagreb, Hrvatski državni arhiv, Metropolitanska knjižnica zagrebačke nadbiskupije, MR 33, MR 133, MR 168; Budapest, National Széchényi Library, Clmae 395, Budapest, National Széchényi Library, Quart. Hung. 1395.

27. Franjo Šanjek, "Blaženi Augustin Kažotić, Trogiranin (o. 1260-1323). Bio-bibliografski podaci" [Blessed Augustin Kažotić from Trogir (ca. 1260-1323). Bio-bibliographical data], Croatica Christiana Periodica 3/4 (1979), 133-137. 
TAble 5 Marginalia in Ms 29

\begin{tabular}{|l|l|}
\hline Folio & Text \\
\hline $40 \mathrm{r}$ & manum suam aperuit inopi et palmas ... \\
\hline $55 \mathrm{v}$ & Cum ad aures regiae mayestatis pervenit[?] \\
\hline $66 \mathrm{v}$ & mulier ... famulum famulus[?] ... milier \\
\hline $67 \mathrm{v}$ & $\begin{array}{l}\text { Venerabili In christo patri et domino spiritali domino Augustino dei et } \\
\text { apostolica gratia Zagrabiensi Episcopo }\end{array}$ \\
\hline $67 \mathrm{v}$ & per quod ave \\
\hline $67 \mathrm{v}$ & $\begin{array}{l}\text { Virgo deum genuit sed si quis quomodo querit / non est nosse meum } \\
\text { sed scio posse deum }\end{array}$ \\
\hline $69 \mathrm{v}$ & $\begin{array}{l}\text { est mala mors capta cum dicitur ananisapta / ananizapta ferit mortem } \\
\text { quam ledere querit }\end{array}$ \\
\hline $70 \mathrm{v}$ & Stepanus Banus \\
\hline $70 \mathrm{v}$ & Stephanus banus sclavonie \\
\hline $70 \mathrm{v}$ & Hic liber et scriptus qui scripsit sit benedictus \\
\hline $70 \mathrm{v}$ & $\begin{array}{l}\text { Finito libro reddatur gratia christo Quis scripsit istud librum ille } \\
\text { benedicat }\end{array}$ \\
\hline Fol. on the back cover & Domine dominus noster quam admirabile est nomen \\
\hline & \\
\hline
\end{tabular}

anything else but that the manuscript was given to Bishop Augustine, which must have happened during his actual residence in Zagreb, i.e. between 1303 and 1318.

The next important marginal inscription might be connected to that regarding Bishop Kažotić; it is an inscription mentioning the Ban of Slavonia with the name Stephanus, which occurs twice. Historical Slavonia occupied the northern part of modern Croatia (including Zagreb), and in the Middle Ages made part of the Kingdom of Hungary, administered by a ban. Several bans of Slavonia bore the name Stephen in the Middle Ages, e.g. István from the genus Gutkeled (1248-1260), Stjepan Bobonić (1310-1316), and Stjepan Lacković (1350-1352). ${ }^{28}$ It is difficult to say whom the inscription refers to, but one is tempted to think that it was the ban who governed the country during the time of Bishop Kažotić, i.e. Ban Bobonić. The inscription raises questions in regard to its meaning and connotations: is it just a casual reference to the lord of the country, made by the owner of the manuscript, or does it imply that the codex had belonged to the ban, who subsequently donated it to Bishop Kažotić? As both marginals naming the ban appear rather informal and accidental, the former assumption seems more likely.

Other marginals, although less relevant to the history of Ms 29, are not without interest. The strange text on fol. $69 \mathrm{v}$ is a spell against death, ${ }^{29}$ and the exotic,

28. Vjekoslav Klaić, "Hrvatski hercezi i bani za Karla Roberta i Ljudevita I. (1301-1382)" [Croatian dukes and bans during the time of Charles Robert and Louis I], Digital Collection of the Croatian Academy of Sciences and Arts (http://dizbi.hazu.hr/), accessed April 2015.

29. The word rendered as "quam" on Table 5 is written in an abbreviated form and could also be read as "qui," which would be grammatically incorrect. The right form of this pronoun is "quae"; "quam" is possible but changes the meaning. 
TABLE 6 Solution of the acronym in the spell

\begin{tabular}{|c|c|}
\hline A & Antidotum \\
\hline $\mathbf{N}$ & Nazareni \\
\hline $\mathbf{A}$ & Aufferat \\
\hline $\mathbf{N}$ & Necem \\
\hline $\mathbf{I}$ & Intoxicationis \\
\hline $\mathbf{S}$ & Sanctificet \\
\hline $\mathbf{A}$ & Alimenta \\
\hline $\mathbf{P}$ & Pocula \\
\hline $\mathbf{T}$ & Trinitas \\
\hline $\mathbf{A}$ & Alma \\
\hline
\end{tabular}

seemingly Greek word "ananisapta" is an acronym standing for a plea to Jesus and the Holy Trinity (Table 6). The spell appears to have been widely known and used. ${ }^{30}$ As Bishop Kažotić wrote about superstition and witchcraft, the marginal inscription of the spell could be somehow associated with him. However, his treatise on superstition does not relate to this sort of conjuring, which, being considered Christian, would be regarded as wholly legitimate in his time. ${ }^{31}$

From all these observations the outline of the history of Ms 29 can be summarized as follows. The manuscript was prepared somewhere in the southern parts of the German Empire, perhaps in the territory of modern Slovenia. Although the place of its production cannot be exactly traced, it is quite certain that by the end of the $13^{\text {th }}$ century it was in Slavonia, and that sometime between 1303 and 1318 it was donated to Bishop Kazotić. Musical insertions, dating roughly from the same period, must have been made in the Diocese of Zagreb, then a suffragan diocese to Kalocsa, and since they were written in Hungarian notation, they must have been executed by someone who was skilled in such notation and very likely educated in one of the Hungarian ecclesiastical centres. It is not known when and under which circumstances Ms 29 came into possession of the Cistercian Abbey of Kostanjevica/Mariabrunn, lying some $60 \mathrm{~km}$ west of Zagreb. There is no sign in the manuscript that would explicitly associate it with that monastery.

30. It is mentioned, among others, in the following works: T. Crofton Croker, Catalogue of a Collection of Ancient and Mediaeval Rings and Personal Ornaments formed for Lady Londesborough (1853), 12; G. W. Thornbury, Shakespeare's England, vol. II (London: Longman, Brown, Green, and Longmans, 1856), 165; Don C. Skemer, Binding Words: Textual Amulets in the Middle Ages (Philadelphia: The Pennsylvania State University Press, 2006), 156.

31. See Franjo Šanjek, "Nadležnost inkvizicije u svjetlu Kažotićevih 'Izlaganja o pitanjima krštavanja slika i drugih praznovjerja"' [Authority of the inquisition in Kažotić's 'Dicta super questionibus de baptizacione ymaginum et aliarum superstitionum'], Chroatica Christiana Periodica 4/5 (1980), 63-77. - On fol. 40r there is a quotation from Prov. 31, 20. On the margin of fol. 67v there is a fairly known distich, included in the catalogue Repertorium hymnologicum, ed. Ulysse Chevalier, vol. III (Louvain: Polleunis et Ceuterick, 1904), 672, n. 34595. The text has been published by Greti Dinkova-Bruun, "Medieval Latin Poetic Anthologies (VII): The Biblical Anthology from York Minster Library (MS. XVI Q 14)," Mediaeval Studies 64 (2002), 89. On fol. $70 \mathrm{v}$ there are two rhymed concluding formulas of the scribe; one of them is incomplete (or incorrect). On the folio containing the "Descriptio Terrae Sanctae" there is the beginning of Ps. 8, very likely written after the folio became part of the binding of Ms 29. 